\title{
Exploring the Creative Economic Potential of Kediri Targeting to Become Creative City on UNESCO Standard and the Indonesia Ministry of Creative Economy (KEMENPAREKRAF)
}

\author{
Mochamad Muchson \\ Program Pascasarjana Universitas Nusantara PGRI Kediri \\ JL. KHA. Dahlan 76 Kota Kediri Jawa Timur Indonesia
}

\begin{abstract}
Unesco has chosen the world's Creative City where there are three followings cities in Indonesia: Pekalongan (2014), Bandung (2015) and Ambon (2019). BEKRAF (KEMENPAREKRAF) in 2019 had chosen Creative City in Indonesia but Kediri City was not included in it. The purpose of this research is to explore the potential of the creative economy of Kediri to match the standard of a Creative City, both the UNESCO version and the BEKRAF version (KEMENPAREKRAF). This study uses a qualitative approach with qualitative descriptive methods (exploration), the research instrument uses were human instruments, how to get informants was by using snowballing sampling and key informants, data collection techniques used was triangulation and data analysis techniques used was analysis of cultural themes. The results shows that 16 sub-sectors of the creative economy of Kediri City are available, it is feasible to propose three following creative economy: crafts (weaving), arts (Jaranan) and culinary (Takwa Tofu). The creativity of making Ikat weaving, Jaranan and takwa tofu is the result of combination of skills, culture and the environment accompanied by science that meets the requirements John Howkins' definition version of creative economy. Weaving Ikat, Jaranan and Takwa tofu give a chance to made Kediri City a Creative City because they meet the requirements of both the UNESCO and BEKRAF versions. Fulfillment of the UNESCO version includes history, cultural and economic development, exhibition and cultural support, entry into the curriculum and extra-curricular of Vocational High Schools and facilitation of exhibition spaces. Meanwhile, the fulfillment of the BEKRAF version is the existence of a quadruple helix, support for the five stages of creative economy development and the existence of leverage, facilitation, empowerment and mentoring.
\end{abstract}

Keywords: Creative Economy, Creativity, Ikat Weaving, Jaranan, Takwa Tofu

DOI: $10.7176 / \mathrm{JESD} / 12-16-06$

Publication date:August $31^{\text {st }} 2021$

\section{Introduction}

In order to increase the contribution of the creative economy to the resilience of the national economy, the government tries to increase the contribution of the creative economy to economic growth (GDP), employment and export value. The following table is about the targets and achievements of the national creative economy sector for $2015-2019$.

Table 1.1 Targets and achievements of the national creative economy sector

\begin{tabular}{|c|c|c|c|c|c|c|c|c|c|c|c|c|c|c|c|c|}
\hline \multirow{2}{*}{ No. } & \multirow{2}{*}{ Indicators } & \multicolumn{3}{|c|}{2015} & \multicolumn{3}{|c|}{2016} & \multicolumn{3}{|c|}{2017} & \multicolumn{3}{|c|}{2018} & \multicolumn{3}{|c|}{2019} \\
\hline & & $\mathrm{T}$ & $\mathrm{R}$ & C (\%) & $\mathrm{T}$ & $\mathrm{R}$ & C (\%) & $\mathrm{T}$ & $\mathrm{R}$ & C (\%) & $\mathrm{T}$ & $\mathrm{R}$ & C (\%) & $\mathrm{T}$ & $\mathrm{R}$ & C (\%) \\
\hline 1 & $\begin{array}{l}\text { The growth } \\
\text { of creative } \\
\text { economy } \\
(\%)\end{array}$ & 7,50 & 7,59 & 101,20 & 8,21 & 4,95 & 101,20 & 8,70 & 5,06 & 88,77 & 5,60 & 5,16 & 92,14 & 5,30 & 5,10 & 96,23 \\
\hline 2 & $\begin{array}{l}\text { Workforce } \\
\text { recruitment } \\
\text { (Million } \\
\text { people) }\end{array}$ & 12,1 & 12,17 & 100,56 & 16,20 & 16,91 & 100,56 & 16,40 & 17,43 & 106,20 & 16,70 & 18,35 & 109,88 & 17,20 & 19,01 & 110,82 \\
\hline 3 & $\begin{array}{l}\text { Creative } \\
\text { product } \\
\text { export value } \\
\text { (Billion } \\
\text { USD) }\end{array}$ & 6,15 & 8,74 & 93,33 & 19,33 & 19,99 & 93,33 & 20,50 & 20,00 & 97,56 & 21,00 & 20,60 & 98,10 & 21,50 & 22,07 & 102,65 \\
\hline
\end{tabular}

Source: Ministry of Tourism and Creative Economy / Tourism and Creative Economy Division (2020).

From the data in above, creative economic growth towards GDP target in 2015 is as follows: (7.50), 2016 (5.21), 2017 (5.70), 2018 (5.60), 2019 (5.30). While the 2015 achievements are (101.20), 2016 (101.20), 2017 (88.77), 2018 (92.14), 2019 (96.23). The periods of target exceeded were in 2015 and 2016, while under the target years were 2017, 2018, 2019 but above 90\% and only one below 90\%, namely 2017 .

The creative economy is able to recruit the workforce (in million people), the target of 2015 (12.1), 2016 (16.28), 2017 (16.40), 2018 (16.70), 2019 (17.20). While the achievements in 2015 were (100.58), 2016 (100.58), 2017 (106.28), 2018 (109.88), 2019 (110.52). The whole year exceeded the target.

The export value of creative products (Billion Dollars) the 2015 target were (6.15), 2016 (19.99), 2017 (20.50), 2018 (21.00), 2019 (21.50). While the 2015 achievements were (93.33), 2016 (93.33), 2017 (97.56), 2018 (98.10), 2019 (102.65). Years that exceeded the target were 2019, while those that did not exceed the target 
were $2015,2016,2017,2018$ but the percentage was close to $100 \%$, it was above $90 \%$.

From the data above, it is found that the creative economy nationally is able to contribute to increasing the resilience of the national economy. The contribution is on the economic growth (GDP), employment and export value so that it needs to be continuously developed and empowered through regulation, facilitation / assistance and finance accessibility.

In the creative industry sector, East Java has a vision to become the center of a leading creative industry and competitive in global level in building a strong and fair system (The Leading Province for Creative Industry). This vision is based on the fact about the diversity of arts, culture, cultural heritage and local creative works and existing local creativity, initiating the government to see the potential of the creative economy as needs.

Qualitatively, the potential of the creative economy in East Java can be viewed in many ways, such as East Java has many international class designers, artists, architects, stage artists, musicians, to producers / directors who are already well-known globally. On the other hand, East Java typical products, such as batik, songket, sculpture, Bromo's uniqueness, and various creations to Pasuruan furniture are well-known overseas.

These qualitative facts also strengthened through a national quantitative study on the mapping of the creative economy contribution of East Java. The mapping picture shows that the creative industry in East Java provides a significant economic contribution to National GDP (4.75\%), employment, export contribution and the number of micro and small businesses involved. These results provide optimism that the creative industry can be used as a strategic alternative industry to answer short term and medium term economy problems: 1) relatively low post-crisis economic growth $(4.5 \%$ average only per year $), 2)$ the need for a decline unemployment rate $(4 \%)$, high poverty rate $(12.55 \%)$, and 3 ) low industrial competitiveness level in East Java (BPS, data to March 2014) in (East Java Provincial Secretariat for Economic Administration Bureau, 2014).

The vision of Kediri City 2020-2024 is Kediri city government is to be advanced and prosperous in harmony. There is a mission in economy field called strengthening the regional economy based on regional potential and developing a fair creative economy. In making the vision to become reality, business processes based are used as the main processes include the main processes, management and support. The main process includes human resources and competitiveness as well as an economy based on excellent potential and a creative economy. The management process includes governance, public services and IT. The supporting process includes secure feeling, comfort and environmental insight (Pemkot Kediri: The Service City, 2020).

In the 2020-2024 RPJMD, strategic issues that will challenge the development of the next five years in Kediri City for the economic sector, namely increasing regional economic competitiveness through increasing the regional economy, controlling inflation, increasing the role of social and creative economy and optimizing the performance of BUMD. There is also a special advance program in the creative economy sector, namely developing "Kampung Keren" (a cool village) in creative and independent (Kediri City Government: The Service City, 2020).

UNESCO established the UNESCO Creative Cities Network (UCCN). This is an effort to increase cooperation with cities identified as cities that have creativity as a strategic factor for sustainable urban development. UCCN has a general goal to place creativity and the cultural industry as a development plan at the local level and cooperating actively at the international level. The UNESCO Creative Cities Network also aims to encourage international cooperation with and between cities committed to investing in creativity as role models for sustainable urban development, social inclusion and a cultural spirit (UNESCO, 2020).

Since 2016 the Creative Economy Division (Bekraf) has had a creative municipal / city assessment program with objective to map ecosystems, potentials, best practices, and problems in developing the municipal / city creative economy system nationally. To become a creative municipal / city, the assessment is carried out by means of PMK3I, this is a Self-Assessment of Creative Regency / City of Indonesia which is carried out on a bottom-up basis where the municipal / city government is the one that proposes to be verified by Bekraf. In this procedure, Bekraf designed a role model that can be used as a reference for municipal / city throughout Indonesia to become an ideal creative municipal / city through assistance summarized in the activities of Creative municipal / City (KaTa Kreatif) (M News, 2019). The advance products of Kediri City as found in the booklet of the Department of Industry, Trade, Mining and Energy of Kediri City are: 1) Bandarkidul Ikat Weaving craft, 2) Bamboo Weaving Crafts, 3) Decorative Glass (Engraving) Crafts, 4) Chicken Feather Sulak Crafts , 5) Craft Pottery Crafts, 6) Tofu Industry, 7) Banana Getuk Industry, 8) Cassava Chips Industry, 9) Leather Shoes Industry, 10) Plywood Industry (Kediri City Government: The Service City, 2020).

Seeing the potential of Kediri City, both from the creative economy (creative industry) and the arts, it is appropriate for Kediri City to propose itself to become a Creative City both the world level (UNESCO version) and national level (Bekraf / Kemenparekaraf version). From the explanation, the data was formulated to the following research problem: which is the creative economy potential of Kediri City to become a Creative City? The purpose of this research is to describe the creative economy potential of Kediri City to become a Creative City. (12) 


\section{Review to The Related Literature}

\subsection{The Definition of Creative Economy}

According to John Howkins in Ginting (2018), Creative Economy is an economic activity that focuses on creativity, cultural heritage and the environment as the foundation for the future. The process of creating additional value based on creativity, culture and the environment, this is the way to give additional value to an economy. The point is productivity that comes from creative people who depend on their scientific abilities.

\subsection{The Economy Orientation Wave Movement}

In the $18^{\text {th }}$ century, industrial revolution caused an economic transformation. The domination of the agricultural sector based on human resources and natural resources was substituted by an economy capital-intensive (machine) based industries. In the 1950s, the economy was driven by science as its main resource in creating additional value. Then in 1995 the creativity-based industrial globalization occurred which made the creative economy grew in together with the development of information technology, this is what is called the 4th wave by John Howkins.

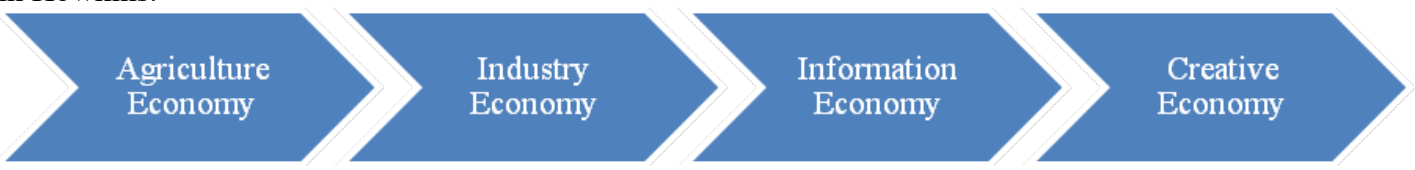

Figure 2.1: Evolution of Production Structure

\subsection{Type and Subsector of Creative Economy}

According to the Presidential decree no 6 of 2015 concerning Creative Economy Division (Bekraf), there are 16 fields / subsectors in the creative economy, namely: 1) application and game development, 2) architecture, 3) interior design, 4) visual communication design, 5) product design, 6) fashion, 7) film, animation, and video, 8) photography, 9) crafts, 10) culinary, 11) music, 12) publishing, 13) advertising, 14) performing arts, 15) fine arts, and 16) television and radio.

\subsection{The Development Models of Creative Economy}

The creative economy development model used is Quad helix, it is collaboration among the government, the private sector (creative business actors), intellectuals and the community (groups of similar business actors).

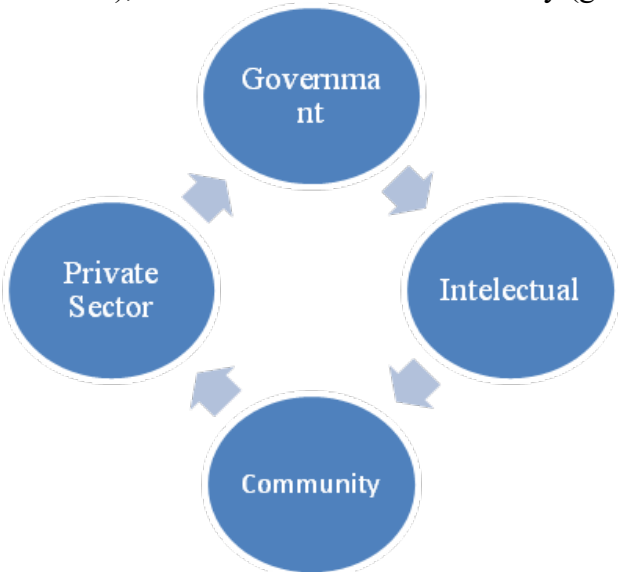

Figure 2.2 The Devepolment of Model of Economy Creative

(The Ministry of Tourism and Economy Creative of Indonesia, 2014)

The four elements of developing this creative model have their specific roles and work together to develop the creative economy. The government has a role as a regulator and creates a conducive atmosphere for the development of creative economy businesses. The private sector or business element has a role in increasing creative economic growth, creating jobs and increasing exports. Intellectuals have the role of fostering a spirit of creativity through the teaching and learning process and the community has the role of encouraging community members to be more creative, continuous in producing, innovative and obedient to rules.

\subsection{What is Creative City?}

The UNESCO Creative Cities Network (UCCN) was founded in 2004 to promote cooperation with and between cities that develop creativity as a strategic factor for sustainable city development. The 246 cities that currently form this network are working together towards similar goal: placing creativity and industrial culture as the main 
point of their development plans at the local level and collaborating actively at the international level. The network covers seven creative areas: craft and folk arts, media arts, film, design, gastronomy, literature and music.

\subsection{Ranking Assessment Techniques}

Creative economic ranking is conducting trough the following mechanism:

1. Self-assessment of creative economy element in the regions.

2. Assessment of the Assessor team established by Bekraf.

The self-assessment indicator consists of 4 elements needed by municipals / cities to manage systemically as creative entities at local, regional, national and global scales. The four elements are:

1. Sixteen subsectors (creative industry sub-sector classification based on Presidential Decree 72 of 2015);

2. Four ABCG actors - quadruple helix (four elements in the development of creative economic activities of a municipal / district;

3. Five stages of creation-production-distribution-consumption-conservation processes (five stages of developing creative economy activities);

4. Two leverage-linkages (Elements which the subsector can apply in the conventional sector).

The ranking is conducting through:

1. Observation and collection of information related to sustainable creative economy activities.

2. Follow and analyze the use of social media by creative economy elements;

3. Appreciation for creative economy activities by various parties.

Besides paying attention to assessments, ranking activities also give attention on the impact of creative economic activities toward employment, increasing exports, increasing GDP, and environmental preservation (Creative Word, 2020).

\section{Research Methodology}

The research design can be seen on the figure below:

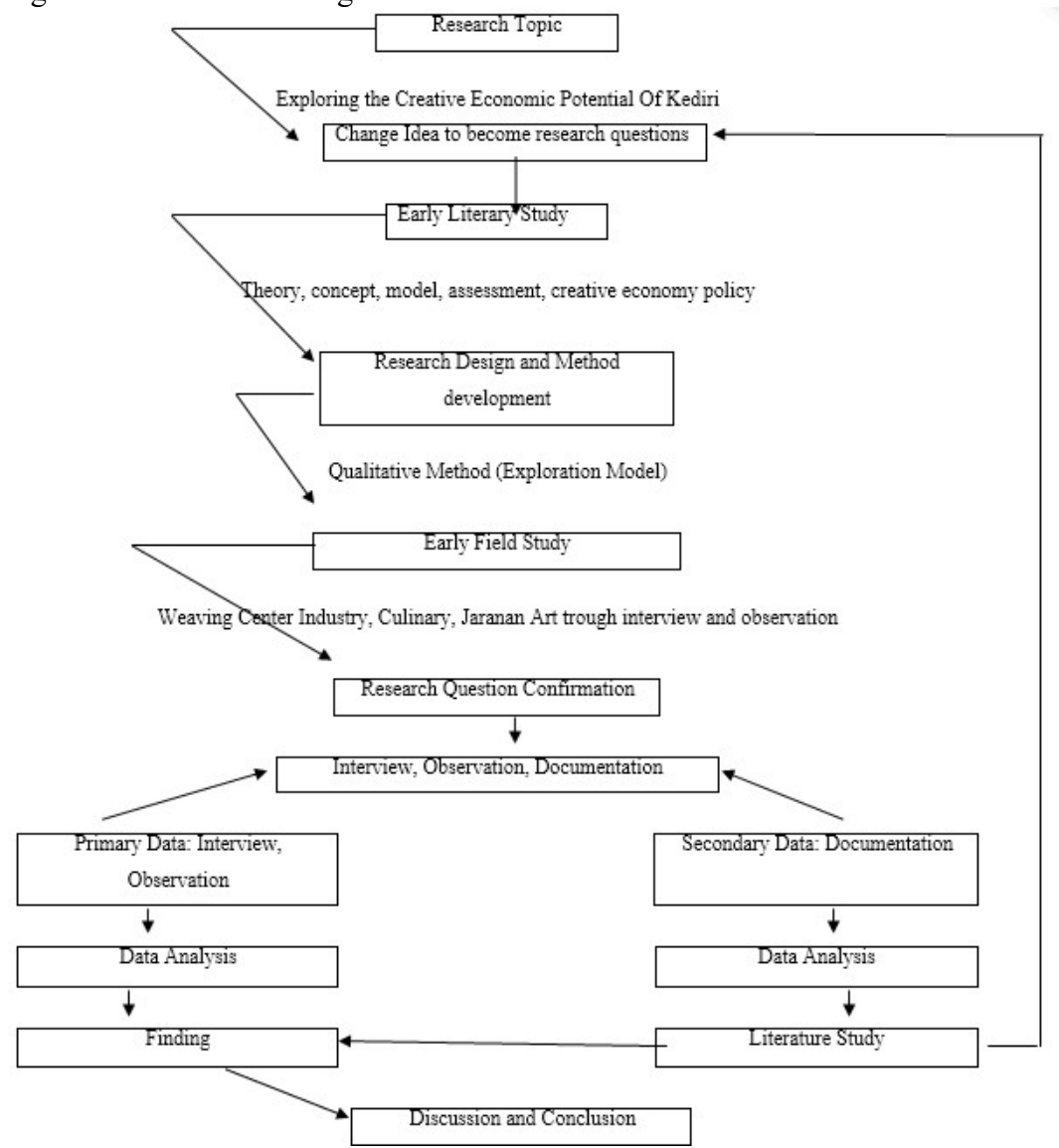

Figure 1: Adaptation research design from (Simatupang, Yudoko, Handayati, Pascasuseno, Permadi, Listiani, 2009) 


\section{Finding and Discussion}

\subsection{The Potential of Creative Economy in Kediri}

The advance products of Kediri City published in the booklet of the Department of Industry, Trade, Mining and Energy of Kediri City are: 1) Bandarkidul Ikat Weaving, 2) Bamboo Weaving Crafts, 3) Decorative Glass (Engraving), 4) Chicken Feather Sulak Crafts , 5) Craft Pottery Crafts, 6) Tofu Industry, 7) Banana Getuk Industry, 8) Cassava Chips Industry, 9) Leather Shoes Industry, 10) Plywood Industry.

Source: Pemkot Kediri The Service City. Produk Unggulan. 23 September 2020. https://www.kedirikota.go.id/page/investasi/15

While the types of arts / performing arts which have developed in Kediri City and have received registration numbers are:

\begin{tabular}{|c|l|l|l|l|l|}
\hline No. & Jenis & $\begin{array}{l}\text { Kecamatan } \\
\text { Mojoroto }\end{array}$ & $\begin{array}{l}\text { Kecamatan } \\
\text { Kota }\end{array}$ & $\begin{array}{l}\text { Kecamatan } \\
\text { Pesantren }\end{array}$ & Total \\
\hline 1. & Jaranan & 43 Groups & 40 Groups & 30 Groups & 113 Groups \\
\hline 2. & Malay orchestra & 12 Groups & 9 Groups & 15 Groups & 36 Groups \\
\hline 3. & Dance Studio & 3 Groups & - & 1 Group & 4 Groups \\
\hline 4. & Shadow Puppet & 2 Groups & - & 5 Groups & 7 Groups \\
\hline 5. & Campursari & 2 Groups & 1 Group & 3 Groups & 6 Groups \\
\hline 6 & Jemblung & 1 Group & - & - & 1 Group \\
\hline 7. & Reog & - & - & 2 Groups & 2 Groups \\
\hline 8. & Ketoprak & - & 2 Groups & 1 Group & 3 Groups \\
\hline Total & & 63 Groups & 52 Groups & 57 Groups & 172 Groups \\
\hline
\end{tabular}

Source: Culture, Tourism, Youth and Sport Authorities of Kediri

(Dewandaru, Purnamaningsih: 2016)

The discussion of the creative economy potential of Kediri City is going to focus on handicrafts or woven handicrafts, the performing arts of Jaranan and culinary of Takwa-Tofu / yellow tofu according to the mapping of 16 creative economy sub-sectors based on Presidential decee of the Republic of Indonesia Number 6 of 2015 concerning the Creative Economy Agency (Bekraf).

\subsection{Weaving}

Weaving Center of Kediri City is located in Bandar Kidul Village, Mojoroto District, Kediri City. Established in 1946 by the first business owner, Mrs. Musriyatin, who owns a traditional machine tool or Non-Machine Weaving Tool (ATBM). The main product of the Weaving is the goyor sarong, which is called the goyor sarong because of the look of "goyor-goyor" (Supple) when it is worn and feels cool when it is worn.

Starting in 2000, in order increase sales, there were some craftsmen who had started exporting sales to several Southeast Asian countries such as Malaysia and Brunei Darussalam and some Middle Eastern countries, although only through exporting agency in Surabaya. In the $2005 \mathrm{~s}$, the still existing craftsmen tried to diversifying their products as an effort to anticipate the high level of competition. They produced Goyor weaving Sarong products with factory woven sarong products, to produce woven fabrics both silk and semi-silk. This woven fabric can be used for various types of wears such as clothes, bags, shoes, mats and various other creative products like woven cloth masker that can help product sales. In various agencies such as the Kediri City government, the private sector and schools are required to wear uniforms made of woven fabrics produced by the Ikat Weaving in Bandar Kidul Village, Mojoroto District, Kediri City. Now, the outlets of the Ikat Weaving business providing various kinds, starting from woven sarongs, woven fabrics, and bags made of woven fabrics, bags, shoes, tablecloths, pillowcases, pencil cases, tissue holders, masks and various other creative products.

With the existence of creativity, innovation and product diversification, of course, it really helps the development of the Weaving business, which only relied on goyor woven sarongs, then improved to various products made from weaving. Weaving craftsmen experienced extraordinary business development with. The development of this business can be seen from the increase in ATBM, better production sites, more various weaving products, having outlets and showrooms both at home and outside, increasing sales, increasing variety of consumers, increasing marketing areas, and so on.

This increase in business received a warm welcome from various parties, including Kediri City Government, the East Java Provincial Government and private agencies. The acceptance was the form of invitation of exhibitions at the local, regional and national levels. In addition, there is also facilitation for providing soft loan and training for human resources. Bank Indonesia also involves in supporting the development of these weaving craftsmen by conducting comparative studies to various regions and providing capital assistance.

With the assistance of various parties, each of these ikat Weaving Businesses in the Bandar Kidul village has started to show extraordinary developments and their products are gradually more known to the wider 
community both locally, regionally, nationally and internationally, especially Southeast Asia and the Middle East. Even the recognition of $i k a t$ weaving products as Indonesian creative products by UNESCO has also raised its value internationally. Support from various parties has allowed Kediri City Ikat Weaving craftsmen to survive, develop and continue to innovate.

Based on the history, actually ikat weaving Kediri has existed since the XII century during the Khadiri Kingdom. A historian from the Netherlands, Gerrit Pieter Rouffaer who conducted research on fabrics in Indonesia, said that the gringsing pattern or double-tie technique where the pattern can only be formed using canting tool has been known and used since the XII century.

\subsection{Jaranan}

In the Javanese Baoesastra Dictionary by W.J.S Poerwadarminta (1939) stated that Jaranan was one of the art forms that existed in Javanese society. Jaranan comes from the word Jaran or Kuda (noun) or Jaranan or horses (a form of activity). Jaranan usually uses woven bamboo (braids) as a Jaran or Horse so that it is named Jaran Kepang or Kuda Kepang. For people who have better economy condition, they usually make Jaran from cowhide or buffalo leather so that it is named Lumping Horse. Historians, Jaranan old figures and also according to legend, Jaranan was a legendary story of the life of the Great King of Khadiri, namely Sri Maharaja Rake Sunjuk Sri Kameswara Sakalabhuwanatustikarana Sarwaniwaryywirya Parakrama Digyottunggadewa or Kameswara who ruled the Khadiri Kingdom (1115-1130 AD).

It was said that the King who was well-known as Panji Asmarabangun and his queen (Dewi Sekartaji / Dewi Kilisuci / Dewi Songgolangit) was a picture of the figure of Dewata Maneges or Dewata Katon, a god who manifested himself as a human. So that his acts and behavior were deserve to be role models for all his people. Everything related to his life has become legends and topic that are told from time to time so that it is eternal until now. Sang Panji is a perfect picture in the conception of traditional Javanese society.

According to Sukatno in Huda (2016: 45) that the art of Jaranan was born from the admiration of the public for the Panji soldiers who were practicing kridaning jurit or practicing warrior techniques, including the agility of riding horses. People imitate it by playing horse using banana stalks. Furthermore, as grassroots, jaranan experienced metamorphoses for a very long time. Gradually, the horses that were originally made from banana stalks changed to made from woven bamboo.

When there were community leaders who owned the gamelan and liked these dances, music was created then. Furthermore, other variants or types of dances that accompany Jaranan had developed. The necessary outfits, costumes and character masks were created. It was gradually took relatively long time, the art of Jaranan came to form we see today.

Based on interviews with Jaranan elders, Jaranan art originated from the shepherds' admiration to the Panji soldiers who were training to fight in the area around Selomangleng Cave and Maskumambang Hill which are now part of the Kediri city administrative area. The dashing and agility of the Panji warriors attracted the attention of shepherds to imitate with banana stalk; this was the forerunner of the art of Jaranan. Panji warriors not only practice warfare but also hunt in the forests of Mount Wilis by horse riding and archery. This hunt earns a lot of results by catching wild boars.

The shepherds were also amazed by the agility of the Panji soldiers in hunting so that they imitated this agility and this was the forerunner of the Srenggi Celeng Dance. Besides that, the shepherds were also interested in the behavior of the Panji warrior horse care. The interaction of horse caretakers with their horses was the source of inspiration for the birth of the dance and figures of Bancak-Doyok and Tembem-Penthul in the art of Jaranan. When the soldiers in the forest met the ghosts of the forest and wild beasts, they could beat them with their supernatural powers of became the inspiration for the Barongan dance. The Jaranan dance has four stages, they are: 1) the Jaranan dance which reflects the dashing and agility of the Panji soldiers in war training, 2) the Celeng Srenggi dance which reflects the Panji warriors technique in hunting Celeng, 3) the Bancak - Doyok dance which reflects the horse caretakers of the Panji warriors. and 4) the Barongan dance, which reflects forest ghosts and wild animals that the Panji warriors meet in the forest.

The Panji legend did not only inspire a Jaranan dance but also extended to the parts of community life like governance and state affairs, irrigation and folk dances such as Wayang Topeng and Wayang Panji. Sang Panji also appears in the tradition of creation keris (dhapur), the carvings in the shape of the heads of Panji and his wife also appear on ani-ani (ancient knives for picking rice) and rakit (wooden sticks for cow or buffalo pairs for carts or plowing fields). According to Huda (2016: 50) "as performing art, Jaranan has several functions as the followings: 1) Supplements of ritual initiation, 2) Purification Rites, 3) Rain request rites, 4) Teaching of Philosophy, 5) Entertainment.

As a performing art, Jaranan has elements to complete the performance. These various elements are a unity so that Jaranan cannot be called an art without complete and mutually supporting elements. According to Huda (2016: 53), there are elements in the Jaranan art performance as follows: 1) Dalang, 2) Gambuh, 3) Ndadi (Trance), 4) Dancer, 5) Sinden, 6) Nayaga. 
The Jaranan art performance has a storyline that begins with the Bopo Suguh ritual, this is the Bopo prayer at the place to be used as an event, this prayer is done by burning incense, the purpose of this prayer is so that the event runs well. The prayer section then continued with Banjaran Cemeti Pusaka, where the Bopos took turns whipping the heirloom whip with the aim of getting rid of various troubles.

Huda (2016: 83) stated that the Jaranan storyline is staged in four acts, each tells a specific storyline as the followings 1) First stage is Jaranan Dance, 2) Second stage is Celeng Srenggi Dance, 3) Third stage is Penthul Tembem Dance, 4) The fourth stage is Barongan Dance.

\subsection{Takwa Tofu / Yellow Tofu}

Everyone agrees that Kediri City is the City of Tofu since, especially, yellow tofu has become the icon of Kediri City. Along the trade center street such as Patimura street, Yos Sudarso street, Trunojoyo street, there are many stores that produce and sell tofu. Even, it has expanded to become people's economic centers as can be found in Jagalan, Pocanan, Pakelan, Tinalan and Bawang villages. Kediri City Government has also decided that tofu, especially Yellow Tofu, as the advance product of Kediri City. Yellow Tofu and its variations products have become special souvenirs of Kediri.

In Kediri, there are various types of tofu and their variations, called White Tofu and Yellow Tofu. Tofu can also be formed into several products such as tofu sticks and tofu chips. Tofu can also be consumed in various types such as fried tofu with chilies, a variants menu for meatballs, tahu campur, thek tofu and others. Tofu is not the original food of Indonesian. Deeper point of view, it is not from Kediri. The term tofu comes from the word tau-hu from the Hokkien language which means fermented soybeans. While takwa comes from the word kwa, this is the Hokkian tribe to who migrated to Indonesia, especially those who settled in Kediri. The Javanese found it was difficult to say the word Kwa which then assimilation and adjustment so that it is called takwa. As a result, it is called Takwa tofu .

In the 1900s there was a massive migration of Chinese citizens to the archipelago, some of them settled on Java Island, Sumatra Island, Kalimantan Island, Sulawesi Island and so on. Some also lived in Kediri include Lauw Soen Hok or better known as Bah Kacung. He was the first person to establish a Tofu Factory in Kediri City in 1912 and is located on Jalan Trunojoyo. This is a home industry, shop and residence and now handled by the third generation. As time goes by in Kediri, there are many tofu and takwa brands, such as LYM, POO, PONG, Surya, LTT, Mickey Mouse, LTH, Panglima, Hayam Wuruk and other people's industrial products with branded or without branded.

\section{Discussion}

\subsection{Ikat Weaving}

Everyone in Kediri agrees that Ikat Weaving produced in Bandar Kidul Village, Mojoroto Subdistrict, is an advance product of Kediri, which is now being worn as office and school uniforms which originally only produced Goyor woven sarongs. In order to face the reduction of sales, the craftsmen have diversified and innovated products, they produce woven, semi-silk and silk fabrics with various products such as clothes, bags, shoes, chair cushion covers, tablecloths, pencil cases, tissue holders and various other creative products.

Seeing from the stages of the manufacturing process starting from the process: 1) plangkan ngeteng, 2) making motive or patterns, 3) tying threads, 4) coloring, 5) penghanian or nyekir, 6) plaque and, 7) weaving, all the process stages needs creativity. Especially at the stage of making a motif or pattern which depends on the creativity of the maker. The motifs or patterns found in the Ikat Weaving Kediri still have some historical motifs such as the Kediren motive like Ceplok, tirtotirjo, loong, salur, gunungan and kuncup and other motive based on consumer demand. Commonly, the owner makes the motive or pattern, and then the next process is continued by the employee because the employees only focus on technical work. The idea of making various motives or patterns is a creative process that most people don't have. This is as the same as the opinion of John Howkins in Ginting (2018), Creative Economy is an economic activity that makes creativity, cultural heritage and the environment as the foundation of the future. The process of creating additionalvalue based on creativity, culture and the environment that gives value to the economy. The point is productivity that comes from creative people who rely on their scientific abilities. Ikat weaving is a creative and innovative product that is born from creativity, cultural heritage and the environment combined with knowledge. Ikat weaving is also an economic product because the purpose is to be sold in order to get income and profit.

Ikat Weaving is adequate the requirements to be proposed Kediri city governmaent as a Creative City because it is fit the elements of the UNESCO version of the Creative City, there are: a) Seeing from the history of Ikat Weaving which is originally comes from Kediri and from has been produced since the days of the Kadhiri Kingdom until now. It has been integrated with the Kediri people. B) Contributing to development culture and economy like the source of community income, provision of employment and regional economic growth. c) Support by cultural exhibitions and festivals. d) Ikat weaving home industry has been frequently visited by schools and universities for various purposes such as for street vendors, compiling papers, business assistance 
and others. e) Facilitating exhibition space.

\subsection{Jaranan}

Jaranan, seen from its appearance and storyline, is identical to a dance. Jaranan performances from start to finish are dominated by the person dancing beside the person who is in a trance. Meanwhile, there are four stages in the storyline as the followings: 1) Jaranan dance, 2) Celeng Senggi dance, 2) Penthul Tembem dance, and 4) Barongan dance, all feature dances. This Jaranan dance was inspired by the story of the Panji warriors who trained for war, which at first was just imitating banana leaves and then developed into braids or bamboo woven and with a long process of time, the Jaranan dance became what we see today.

No doubt that dance is creativity, not everyone is able to create a dance. Besides, the Jaranan dance is also a cultural heritage and environmental condition shaped it. Outside art form, the Jaranan dance also has economic value. Usually people who enlist Jaranan will get a number of rewards from their hard work as Jaranan dancers. The "jobs" as a Jaranan dancer could be seen as a hobby, a side job or a main job. Usually a Jaranan group is contracted by people who have events, both initiation events (celebrating births, circumcisions, weddings) and purification rituals (ruwatan and village alms) and will get a sum of money which will be distributed to all members involved. Jaranan is not only an artistic activity but also an economic activity that generates income. This means that Jaranan fulfills the elements of the creative economy as stated by John Howkins in Ginting (2018) that the Creative Economy is an economic activity that makes creativity, cultural heritage and the environment as the foundation of the future. The process of creating additional value based on creativity, culture and the environment is what additional value to an economy. The point is productivity that comes from creative people who rely on their scientific abilities. The more elites who contracts Jaranan, the greater the economic value of Jaranan's contract value. Many parties usually contract Jaranan, such as individuals, communities, private institutions and government agencies.

Jaranan also increases community economic activities. There are 113 Jaranan groups registered at the Department of Culture, Tourism, Youth and Sports in Kediri in 2016. These groups usually receive performing contract of various events both inside the City of Kediri and outside the City of Kediri. Jaranan is very familiar with the people of Kediri and its surroundings, almost every day we can watch Jaranan performances int various events. Jaranan has also been documented in the form of CDs which are traded in stalls and consumers are from children to adults and the elderly. Jaranan has also expanded to inspire musicians to create a musical genre known as dangdut koplo that is popular with the public and brings high economic value to the producers and singers.

Jaranan is adequate the requirements to be proposed by Kediri as a Creative City because it has all elements of the UNESCO version as the Creative City, the followings: a) Seeing from the history of Jaranan, the combination of the City of Kediri and from the days of the Kadhiri Kingdom up to now has been integrated with the Kediri people. b) Contribute to cultural and economic development as an alternative source of income for the community and providing employment opportunities. c) Supported by cultural exhibitions and festivals. d) Jaranan has entered school through extra-curricular activities. e) Facilitated by performance space. (45)

\subsection{Takwa Tofu}

Everyone agrees that Kediri is a Tofu City because there is a Yellow Tofu or Takwa Tofu produced only in Kediri and not found in other regions in Indonesia. Many tofus produced all around the archipelago, but most of them are white tofu like Sumedang tofu and white tofu from other regions. Tracing the history of Tofu in Kediri, it was first produced by Chinese traders around the XII century and started producing for commercial purposes in 1912 by Lauw Soen Hok or Bah Kacung. Not everyone has the skills to make Tofu because certain abilities are needed to process it.

Until 1948 Bah Kacung was the only person who produced Takwa tofu, then in 1948 his relative from China named Liem Go May also produced it and until now the two companies still exist under the brands Bah Kacung's Yellow Tofu and Liem's Yellow Tofu. Around 1970, new producers appeared producing Yellow Tofu and White Tofu in all around Kediri City. The common thing was workers from the two companies resign and set up their own tofu businesses.

Seeing the tofu production process, started from washing, milling, cooking, filtering, giving cukak, pressing, cutting, cooking again with turmeric, so Yellow Tofu requires creativity, especially with innovation, namely by giving it a yellow color. So, as stated by John Howkins in Ginting (2018), the Creative Economy is an economic activity that makes creativity, cultural heritage and the environment the foundation of the future. The process of creating added value based on creativity, culture and the environment is what adds value to an economy. The point is productivity that comes from creative people who rely on their scientific abilities. Tahu Kuning or Tahu Takwa is a creative and innovative product that was born from creativity, cultural heritage and environment combined with knowledge. Yellow tofu or Takwa tofu is also an economic product because its purpose is to be sold in order to get income and profit.

Takwa tofu or Tahu Kuning is adequate to meet the requirements to be proposed by Kediri city government 
as a Creative City because it has all the elements of the UNESCO version of the Creative City, they are: a) seeing from the historical side that Takwa tofu was originally found and improved in Kediri. b) Contribution to cultural and economic development as the source of community income, provision of employment and regional economic growth. c) Support through cultural exhibitions and festivals. d) Takwa Tofu or Tahu Kuning has become part of schools, especially Vocational High School (culinary) as practical material. d) Facilitated for exhibition space.

Ikat Weaving, Jaranan and Takwa Tofu or Tahu Kuning meet the requirements to be proposed by Kediri City government as a Creative City because they have the elements of the Bekraf version of the Creative City (Kemenparekraf), As followings:

1. There are four ABCG-quadruple helix actors (four actors in the development of creative economy are government, business entity, private sector and the community).

2. The city government supports five stages: creation-production-distribution-consumption-conservation (five elements of developing creative economic activities);

3. Two linkages - leverage (elements which sub-sectors can apply in the conventional sector) are in the form of facilitation, empowerment and mentoring.

\section{Conclusion}

a. Ikat weaving has become a advance product and icon of the City of Kediri. Its products, which were originally only Goyor Gloves, have now developed into several products like fabrics, both woven fabrics, semi-silk fabrics, silk fabrics and are used for various uses such as clothes, bags, shoes, sandals, wallets, chair cushion covers, tablecloths, pencil cases., tissue holders and now what is trending are woven masks and various other creative products. The creativity of making Ikat Weaving has fulfilled the definition of the creative economy version of John Howkins and Kediri City deserves to be proposed to be a Creative City both by UNESCO and BEKRAF (Kemenparekraf RI).

b. Jaranan has become a culture in Kediri City; many Jaranan groups have developed in Kediri City. Jaranan has become a leading art culture based in Kediri. This Jaranan dance is a person's creativity which is the result of a combination of skills, culture and the environment accompanied by knowledge so that the Jaranan dance adequate for fulfilling the elements of the creative economy. The economy side is seen from the Jaranan groups which are contracted when there are individual events (circumcision, marriage), purification (ruwatan, village purification), local government events and others. Jaranan is in line with John Howkins' definition of creative economy and deserves to be proposed by the City of Kediri Government as a Creative City, both by UNESCO and BEKRAF RI.

c. Takwa tofu is an advance product and icon of the City of Kediri. Creativity in making tofu is in line with John Howkins' definition of creative economy, which is stated that an economic activity provides additional value that comes from creativity, culture, the environment and is combined with the knowledge that is owned. Takwa tofu also qualified for Kediri to become a Creative City because it meets the requirements of both the UNESCO and BEKRAF versions. (51)

\section{SUGGESTION}

a. It is the right time for the City of Kediri to explore the creative economy, especially the advance products and icons of the City of Kediri like Ikat weaving, Jaranan and Takwa tofu.

b. It is the right time for Kediri City to propose to be a Creative City, both by UNESCO and BEKRAF, through advance products and icons of Kediri City such as Ikat weaving, Jaranan and Takwa tofu.

c. The quadruple helix cooperation needs to be improved so that the creative economy of Kediri City can be more developed in terms of production, sales, regional economic growth and culture.

d. It is recommended that the Kediri City government be the core for the development of the creative economy in the form of exhibitions, cultural festivals, facilitating exhibition spaces, empowerment and assistance.

e. It requires awareness of all elements to realize that the creative economy is an economy of the future because it is based on creativity, culture and the environment and is a renewable resource in the middle of limited natural resources.

\section{References}

Acurat.co. 2019. 5 Kota Kreatif Dunia Versi UNESCO, Ada 3 dari Indonesia. In https://akurat.co/news/id 843005-read-5-kota-kreatif-dunia-versi-unesco-ada-3-dari-indonesia, retreived 20 Agustus 2020.

Biro Administrasi Perekonomian Sekda Provinsi Jawa Timur. 2014. Roadmap Pengembangan Ekonomi Kreatif Jawa Timur 2014-2018. In https://porekraf.jatimprov.go.id/documents/ROADMAP-EKONOMI-KREATIFJATIM-2014-2018.pdf, retrieved 7 September 2020.

Disbudparpora Kota Kediri. 2020. Induk Kesenian. In https://www.kediritourism.net/, Retrevied 23 September 
2020.

Dewandaru, Bothy; Purnamaningsih, Nining. 2016. Strategi In Memajukan Industri Kreatif dan Pengembangan Ekonomi Lokal Sebagai Daya Tarik Wisata (Studi pada Kesenian Jaranan di Kota Kediri). Jurnal Ekonomi Universitas Kadiri Vol. 1. No. 2. September 2016. 170 - 187.

Ginting, Ari Mulianta. 2018. Pengaruh Ekonomi Kreatif Terhadap Perekonomian Nasional. Strategi Pengembangan Ekonomi Kreatif. Jakata. Yayasan Pustaka Obor Indonesia.

Kata Kreatif. 2020. Penilaian Mandiri Kabupaten Kota Kreatif Indonesia -PM3I. In https://www.kotakreatif.id/file/SISTEM\%20EKONOMI\%20KREATIF\%2019\%2008\%202016\%20[LO].pd f, retreived 25 Agustus 2020.

Kartika, Metasari; Hendarmin. 2018. Pemetaan Ekonomi Kreatif Subsektor Kuliner di Kota Pontianak. Jurnal Ekonomi Bisnis dan Kewirausahaan. Vol.7, No.1, 58-71.

Kementerian Pariwisata dan Ekonomi Kreatif/Badan Pariwisata dan Ekonomi Kreatif. Rencana Strategis Kementerian Pariwisata dan Ekonomi Kreatif/Badan Pariwisata dan Ekonomi Kreatif 2020-2024. In media_1598887965_Rencana_strategis_2020-2024\%20(6).pdf, retreived 5 September 2020.

Kementerian Pariwisata dan Ekonomi Kreatif (2014), Ekonomi Kreatif: Kekuatan Baru Indonesia Menuju 2025.

M News. 2019. 10 Kabupaten/Kota Kreatif se-Indonesia Tahun 2019. https://mnews.co.id/read/beritalainnya/10-kabupatenkota-kreatif-se-indonesia-tahun-2019/, retreived 23 September 2020

Memo.com. 2019. Kampung Kreatif dan Independen, Kembangkan Ekonomi Kreatif, Potensi Wisata, dan Budaya pada Kelurahan. In https://koranmemo.com/kampung-kreatif-dan-independen-kembangkanekonomi-keratif-potentsi-wisata-dan-budaya-pada-kelurahan/ retreived 30 Agustus 2020.

Pemkot Kediri: The Service City. 2020. Produk Unggulan. In https://www.kedirikota.go.id/page/investasi/15, retreived 23 September 2020.

Peraturan Menteri Pariwisata dan Ekonomi Kreatif/Kepada Badan Pariwisata dan Ekonomi Kreatif Republik Indonesia Nomor 12 Tahun 2020 tentang Rencana Strategis Menteri Pariwisata dan Ekonomi Kreatif/Kepada Badan Pariwisata dan Ekonomi Kreatif Tahun 2020-2024.

Peraturan Presiden Republik Indonesia Nomor 6 Tahun 2015 tentang Badan Ekonomi Kreatif (Bekraf).

Pemkot Kediri: The Service City. 2020. Walikota Kediri Paparkan Strategi Peningkatan SAKIP Kota Kediri menuju A. in https://kedirikota.go.id/p/berita/1019562/walikota-kediri-paparkan-strategi-peningkatansakip-kota-kediri-menuju-a, retreived 23 September 2020.

Pemkot Kediri: The Service City. 2020. Mas Abu Paparkan RPJMD Kota Kediri 2020-2024 In Sidang Paripurna di DPRD Kota Kediri. In https://kedirikota.go.id/p/berita/1019167/mas-abu-paparkan-rpjmd-kota-kediri2020-2024-in-sidang-paripurna-di-dprd-kota-kediri, retreived 25 September 2020.

Suparta, I Wayan. Strategi Pengembangan Ekonomi Kreatif untuk Mendorong Pertumbuhan Ekonomi di Kota Bandar lampung. Jurusan Ekonomi Pembangunan Universitas Lampung.

Sumar'in, Andiono, Yuliansah. 2017. Pengembangan Ekonomi Kreatif Berbasis Wisata Budaya: Studi Kasus pada Pengrajin Tenun di Kabupaten Sambas. Jurnal Ekonomi Bisnis dan Kewirausahaan. Vol. 6 , No. 1, 117.

Simatupang, Togar M., dkk. 2008. Analisis Kebijakan Pengembangan Industri Kreatif di Kota Bandung. Sekolah Bisnis dan Manajemen Institut Teknologi bandung. Volume 8. Number 1.

UNESCO. 2020. Creative Cities Network. in https://en.unesco.org/creative-cities, retreived 27 September 2020. 